\author{
Aleksandra Minkwitz \\ ORCID 0000-0002-6994-3045 \\ Uniwersytet im. Adama Mickiewicza w Poznaniu \\ Katedra Turystyki i Rekreacji \\ aleksandra.minkwitz@amu.edu.pl
}

\title{
MOŻLIWOŚCI WYKORZYSTANIA SERWISU TRIPADVISOR JAKO ŹRÓDŁA DANYCH NA ETAPIE ICH GROMADZENIA W PLANOWANIU ROZWOJU TURYSTYKI W SKALI LOKALNEJ
}

\begin{abstract}
Abstrakt: Artykuł stanowi próbę odpowiedzi na pytanie, czy serwisy społecznościowe mogą być efektywnym źródłem danych, przydatnych w kontekście planowania turystyki w skali lokalnej. W pierwszej części artykułu opisano, jaką rolę pełnią media społecznościowe w przemyśle turystycznym, zawarto syntetyczne omówienie najczęściej pojawiających się tematów badań związanych z wykorzystaniem MS w turystyce, a także scharakteryzowano serwis społecznościowy TripAdvisor, będący przedmiotem badania. W drugiej części przedstawiono wyniki przeprowadzonego z wykorzystaniem serwisu badania, którym objęto odpowiednio po 30 najpopularniejszych hoteli, restauracji oraz atrakcji turystycznych $\mathrm{w}$ Poznaniu. Rezultaty badania przedstawiono za pomocą pięciu map wynikowych. Rezultaty opatrzone są komentarzem na temat zagrożeń, z którymi związana jest analiza danych tego typu, a także możliwych przyszłych kierunków badań.
\end{abstract}

Słowa kluczowe: media społecznościowe w turystyce, Web 2.0, TripAdvisor, UGC, planowanie rozwoju turystyki.

\section{WPROWADZENIE}

W ciągu ostatnich kilku dekad turystyka stała się jednym z największych i najszybciej rozwijających się gałęzi przemysłu. Odgrywa ona obecnie niemałą rolę w stymulowaniu wzrostu gospodarczego, w szczególności poprzez tworzenie nowych miejsc pracy, generowanie przychodów z eksportu, a także rozwój infrastruktury (UNWTO 2017). Zwiększająca się wciąż liczba nowych destynacji turystycznych spowodowała nagły wzrost konkurencyjności. W konsekwencji przed decydentami zostało postawione nowe wyzwanie, jakim jest konieczność przejścia od nieco przypadkowego sposobu wyznaczania celów strategicznych do podejścia bardziej przemyślanego i uporządkowanego, pozwalającego odnaleźć się $\mathrm{w}$ dynamicznie zmieniających się warunkach (LIU, SIGUAW, ENZ 2008).

Działanie $\mathrm{w}$ tak zmieniającym się $\mathrm{i}$ chaotycznym środowisku (PHILLIPS, MOUTINHO 2014) wymaga planowania strategicznego, nie tylko na poziomie przedsiębiorstw działających na rynku usług turystycznych, ale również wśród zespołów opracowujących plany rozwoju turystyki w skali lokalnej.

Jednym z głównych problemów, z jakimi borykają się zespoły planujące, jest pozyskanie danych o frekwencji w atrakcjach turystycznych. Tylko część wła- ścicieli/organizatorów atrakcji prowadzi sprzedaż biletów, co pozwala na gromadzenie danych o liczbie odwiedzających. Są to głównie muzea, parki rozrywki, eventy oraz parki narodowe (KRUCZEK 2016a). Pozyskanie informacji na temat pozostałych atrakcji wymagałoby zastosowania innej metody, przez co porównywanie wyników byłoby utrudnione.

Od kilku lat zwraca się coraz większą uwagę na możliwości, jakie dają lub potencjalnie mogą dać turystyce $\mathrm{w}$ tym zakresie media społecznościowe (MS). Stale rosnące zainteresowanie tematyką MS spowodowane jest skalą tego zjawiska. Spośród niemal 7,6 mld osób żyjących na świecie już ponad $42 \%$ stanowią aktywni użytkownicy mediów społecznościowych (www. wearesocial.com).

Badania pokazują, że internauci chętnie dzielą się w przestrzeni wirtualnej swoimi przeżyciami, w tym również wrażeniami z podróży (FOTIS, BUHALIS, ROSSIDES 2012). Generowane przez użytkowników Internetu wpisy (user generated content) tworzą zbiór danych, który po uprzednim uporządkowaniu może stanowić wartościowe źródło informacji na temat preferencji konsumentów na rynku turystycznym (POLAŃSKA, WASSILEW 2015). W szybko zmieniającym się społe- 
czeństwie konieczne jest ciągłe analizowanie generowanych strumieni danych, ponieważ z powstającego szumu informacyjnego można wyłapać sygnały świadczące o zaistnieniu nowego trendu (MCAFEE, BRYNJOLFSSON 2012).

Niniejszy artykuł stanowi próbę odpowiedzi na pytanie, czy serwisy społecznościowe mogą być efektywnym źródłem danych, przydatnych w planowaniu turystyki w skali lokalnej. W pierwszej części tekstu opisano, jaką rolę pełnią media społecznościowe w przemyśle turystycznym, omówiono w sposób syntetyczny najczęściej pojawiające się tematy badań dotyczących wykorzystania MS w turystyce, a także scharakteryzowano serwis społecznościowy TripAdvisor, będący przedmiotem badania. $W$ drugiej części artykułu przedstawiono wyniki przeprowadzonego z wykorzystaniem serwisu badania, którym objęto odpowiednio po 30 najpopularniejszych hoteli, restauracji oraz atrakcji turystycznych $\mathrm{w}$ Poznaniu. Sformułowano problem badawczy dotyczący zastosowania tzw. nowych mediów w turystyce. Postawiono hipotezę: serwisy społecznościowe mogą stanowić efektywne źródło informacji, przydatnych w planowaniu turystyki w skali lokalnej na etapie gromadzenia danych. Rezultaty przeprowadzonych studiów przedstawiono za pomoca pięciu map wynikowych. Wyniki opatrzone są komentarzem dotyczącym zagrożeń, z jakimi związana jest analiza danych tego typu, a także możliwych przyszłych kierunków badań.

\section{MEDIA SPOLECZNOŚCIOWE W TURYSTYCE}

Media społecznościowe, w takim kształcie, w jakim obecnie mamy z nimi do czynienia, są najbardziej zaawansowaną formą realizacją idei, której źródła należałoby szukać u podstaw koncepcji samego Internetu - sieci łączącej wszystkich jej użytkowników w sposób interaktywny, na zasadzie równego dostępu, eliminującej barierę, jaką jest odległość pomiędzy poszczególnymi osobami (PUDEŁKO 2017). W dzisiejszych czasach Internet, to już nie tylko statyczne strony internetowe, ale dynamiczne platformy, na których środek ciężkości przeniesiony jest $z$ jednego twórcy na wielu użytkowników. Internauci równocześnie występują w roli konsumentów i producentów treści (BERTHON $\mathrm{i}$ in. 2012).

Ewolucyjnie wypracowana zmiana w sposobie myślenia o formie, w której odbywa się komunikacja w sieci, określana jest terminem Web 2.0 (O'REILLY 2005). Web 2.0 stanowi zatem pewną ideologię, w duchu której tworzona jest przestrzeń do funkcjonowania MS. KAPLAN i HAENLEIN definiują MS jako „grupę bazujących na internetowych rozwiązaniach aplikacji, które opierają się na ideologicznych i technologicznych podstawach Web 2.0, i które to umożliwiają tworzenie i wymianę wygenerowanych przez użytkowników treści" (KAPLAN, HAENLEIN 2010, s. 61).

MS stały się narzędziem szeroko wykorzystywanym w turystyce. Istnieje wiele portali turystycznych, działających na całym świecie, które gromadzą konsumentów oraz przedsiębiorstwa turystyczne i umożliwiają komunikację pomiędzy nimi. Do najpopularniejszych portali tego typu należą Yelp, znajdujący się na 196. miejscu w światowym rankingu najczęściej odwiedzanych stron internetowych (www.alexa.com 2018) oraz serwis TripAdvisor, który zajmuje 246 miejsce na tej liście. Pomimo że obydwa portale mają bardzo podobną funkcjonalność, to zauważalne jest wyraźne zróżnicowanie ich popularności w poszczególnych regionach świata. Serwis Yelp jest najczęściej wykorzystywanym serwisem w Stanach Zjednoczonych, w Europie natomiast większym powodzeniem cieszy się TripAdvisor (https:/ / www.alexa.com/site info/tripadvisor.com ).

Z przeprowadzonego przez autorkę przeglądu literatury wynika, że rozważania na temat połączenia MS z przemysłem turystycznym koncentrują się głównie wokół zagadnień dotyczących: wzrostu znaczenia MS w marketingu destynacji turystycznych (HAYS, PAGE, BUHALIS 2013, BRZEZIŃSKI, JASIŃSKI 2014, SZROMNIK 2012), wykorzystania MS w kreowaniu wizerunku restauracji/hotelu (CHAN, GUILLET 2011, KWOK, YU 2013), wpływu MS na zachowania turystów (LIU, SIGUAW, ENZ 2008, MUNAR, JACOBSEN 2014) i wykorzystania MS w procesie planowania podróży (XIANG, GRETZEL 2010, FOTIS, BuHALIS, ROSSIDES 2012).

Choć zagadnienie mediów społecznościowych w turystyce jest szeroko opisywane, to wciąż jednak brakuje opracowań dotyczących gromadzenia informacji z portali turystycznych, jak również analizy tych danych, zarówno ilościowych, jak i jakościowych.

\section{SERWIS TRIPADVISOR}

TripAdvisor jest amerykańskim agregatorem opinii, założonym w lutym 2000 roku przez Stephena Kraufera i Langleya Steinerta. Witryna oparta jest na założeniu, że turyści planujący swoją podróż polegają na sądach innych podróżnych lub traktują je jako dodatkową pomoc w podejmowaniu decyzji (MIGUÉNS, BAGGIO, COSTA 2008). W ciaggu ostatnich 18 lat serwis zgromadził $661 \mathrm{mln}$ opinii (dane z 2018 r.) o hotelach, restauracjach i atrakcjach turystycznych. W swojej ofercie posiada on również interaktywne fora dla podróżników, dostępne także w języku polskim. Firma 
TripAdvisor świadczy swoje usługi za pomocą witryny internetowej w 49 krajach i gromadzi informacje o wszystkich państwach na świecie. Średnia miesięczna liczba użytkowników to $456 \mathrm{mln}$ (tripadvisor.me dia room.com).

TripAdvisor jest medium kolaboratywnym, funkcjonuje dzięki współpracy wielu jednostek (ang. crowdsourced), dostarczających opinie o produktach turystycznych. Na tej podstawie tworzony jest ranking, który stanowi dobro wspólne danej społeczności (HOWE 2009).

Wypowiedzi użytkowników serwisu na temat obiektów turystycznych gromadzone są w formie oceny w pięciostopniowej skali, gdzie 5 oznacza "doskonałe”, a 1 - „okropne”. Dodatkowo każdy użytkownik ma możliwość dodania krótkiego opisu swoich wrażeń z odwiedzin w obiekcie. Serwis sugeruje recenzującym, co powinno zostać zawarte w takiej opinii. Najczęściej wypowiedzi dotyczą rodzajów aktywności, które można podejmować w danym miejscu, udogodnień, dodatkowych atrakcji w pobliżu, ilości spędzonego tam czasu czy największych wad odwiedzanej atrakcji turystycznej. Każda $z$ wypowiedzi może być dodana w dowolnym języku, a część z nich jest automatycznie tłumaczona na inne języki.

Wiarygodność opinii jest kwestią często poruszaną w dyskursie naukowym (AYEH, AU, LAW 2013, BANERJEE, CHUA 2013, ZAJADACZ 2017). Krytycy zwracają uwage na to, że w serwisie istnieje możliwość dodawania bezpodstawnych opinii pozytywnych - przez zainteresowany obiekt, a także negatywnych - przez konkurencję. Nie jest możliwe określenie, jaką część wszystkich ocen użytkowników stanowią opinie nieprawdziwe. Ze względu na groźbę nadużyć, każda wypowiedź przed jej upublicznieniem jest weryfikowana przez pracownika firmy. TripAdvisor podejmuje również szereg działań zmierzających do ograniczenia procederu celowego obniżania pozycji w rankingu czy umieszczania ostrzeżenia na stronie obiektu, a także współpracuje $\mathrm{z}$ organami ścigania w celu wykrywania oszustw. W czerwcu 2018 r. właściciel włoskiego przedsiębiorstwa PromoSalento, zajmującego się sprzedażą usługi dodawania opinii, został uznany za winnego dokonywania oszustw poprzez posługiwanie się fałszywą tożsamością i skazany na dziewięć miesięcy po-zbawienia wolności (tripadvisor.com).

Serwis może być źródłem danych zarówno ilościowych, jak i jakościowych. Pozwala na pozyskanie informacji o konkretnym obszarze, np. o mieście, a także o rodzaju działalności, np. atrakcje turystyczne. Dzięki temu możliwe jest uzupełnianie luk na etapie pozyskiwania danych pierwotnych. Opinie użytkowników są gromadzone na bieżąco, co pozwala na analizowanie dynamiki zmian i jest przydatne na etapie monitoringu i ewaluacji.

\section{CELE I METODY}

Celem niniejszego artykułu jest przedstawienie możliwości, jakie otwiera serwis TripAdvisor w zakresie pozyskania informacji o preferencjach osób odwiedzajacych konkretne destynacje. Informacje te są szczególnie istotne na etapie gromadzenia danych podczas planowania rozwoju turystyki w skali lokalnej. Badanie opisane $\mathrm{w}$ artykule jest próbą weryfikacji tychże możliwości, choć należałoby tu zaznaczyć, że stanowi ono niewielki wycinek potencjału, jaki tkwi w danych zgromadzonych w serwisie.

Celem badania jest identyfikacja i analiza położenia najchętniej ocenianych obiektów, zlokalizowanych w Poznaniu. Do próby badawczej przyjęto informacje pozyskane $\mathrm{z}$ serwisu TripAdvisor.pl, dotyczące 30 atrakcji turystycznych, 30 hoteli i 30 restauracji, znajdujących się w tym mieście. Za kryterium doboru do próby obrano ranking najpopularniejszych miejsc, przy czym popularność jest tutaj mierzona liczbą recenzji, bez względu na wysokość oceny uzyskanej przez obiekt. Zrezygnowano z uwzględniania pozycji najwyżej ocenianych, ze względu na fakt, że zebrana w ten sposób próba zawierałaby niemal wyłącznie lokalizacje nowo utworzone, które najczęściej uzyskiwały najlepszą ocenę (5), ale posiadają niewiele, tj. od kilku do kilkunastu recenzji, i w związku z tym mają niewielką wartość diagnostyczną. Funkcjonalność strony internetowej TripAdvisor.com pozwala na sortowanie obiektów według popularności, jednak metoda, zgodnie z którą ustala się ranking, jest niejasna, dlatego zrezygnowano z zastosowania tego kryterium. Zakres czasowy badania obejmuje wszystkie opinie umieszczone przez użytkowników portalu do 1 stycznia 2018 r.

Analizy i wizualizacji danych dokonano za pomocą metod geoinformacyjnych, w tym mapy skupień, narzędzia bufor (ekwidystanta $1000 \mathrm{~m}$ ) oraz poligonów Woronoja. Na podstawie zebranych informacji sporządzone zostały mapy, obrazujące zainteresowanie użytkowników serwisu obiektami turystycznymi. Analizy przeprowadzono w oparciu o dane topograficzne $z$ rejonu Poznania i powiatu poznańskiego. Do sporządzenia analiz wykorzystano informacje dotyczące granic Poznania, pochodzące z Głównego Urzędu Geodezji i Kartografii.

\section{WYNIKI}

Atrakcje zidentyfikowane za pomocą wyżej opisanej metody wraz z odpowiadającą im liczbą recenzji zostały zaprezentowane $\mathrm{w}$ tab. $1 . \mathrm{W}$ tab. 2 zaprezentowano natomiast obiekty uznane za najpopularniejsze 
w wyniku badania przeprowadzonego przez KRUCZKA (2016b) oraz Poznańską Lokalną Organizację Turystyczną (2016). W tabeli tej podano także liczbę odwiedzających te miejsca w 2015 r.

Porównanie obu tabel pozwoliło na wskazanie obiektów powtarzających się - zostały one oznaczone kolorem szarym. Należy zauważyć, że dane dotyczące frekwencji, zawarte $\mathrm{w}$ tab. 2, odnoszą się tylko do obiektów, w których prowadzona jest sprzedaż biletów, natomiast pominięto tu wszystkie inne atrakcje, w przypadku których badanie liczby odwiedzających w ten sposób nie było możliwe. Należy również zwrócić uwagę na zakres czasowy - w tab. 1 zaprezentowano dane uwzględniające wszystkie recenzje opublikowane na portalu od początku jego funkcjonowania do końca roku 2017, natomiast w tab. 2 umieszczono informacje o liczbie odwiedzających wyłącznie $\mathrm{z}$ roku 2015. Zauważa się zbieżność wyników obu przeprowadzonych analiz - podobne atrakcje uznano za najpopularniejsze, bazując na danych $z$ portalu Trip Advisor oraz na rezultatach badania liczby odwiedzających.

Tab. 1. Najczęściej oceniane atrakcje w Poznaniu

\begin{tabular}{|r|l|c|}
\hline Lp. & \multicolumn{1}{|c|}{ Nazwa atrakcji } & $\begin{array}{c}\text { Liczba } \\
\text { recenzji }\end{array}$ \\
\hline 1 & Stary Rynek & 1872 \\
\hline 2 & Jezioro Maltańskie & 635 \\
\hline 3 & Park Cytadela & 501 \\
\hline 4 & Rogalowe Muzeum & 472 \\
\hline 5 & Bazylika Matki Boskiej Nieustającej Pomocy & 439 \\
& & \\
\hline 6 & i św. Marii Magdaleny & \\
\hline 7 & Ratusz poznański & 425 \\
\hline 8 & Palmiarnia Poznańska & 376 \\
\hline 9 & Katedra pw. św. św. Apostołów Piotra i Pawła & 333 \\
\hline 10 & Stare Zoo w Poznaniu & 284 \\
\hline 11 & Koziołki poznańskie & 276 \\
\hline 12 & Brama Poznania & 256 \\
\hline 13 & Ostrów Tumski & 238 \\
\hline 14 & Kolejka Miniaturowa Maltanka & 149 \\
\hline 15 & Ogród Botaniczny UAM w Poznaniu & 134 \\
\hline 16 & Muzeum Narodowe w Poznaniu & 129 \\
\hline 17 & Lech Browary Wielkopolski & 119 \\
\hline 18 & Centrum Informacji Turystycznej & 117 \\
\hline 19 & Centrum Kultury Zamek & 116 \\
\hline 20 & Poznań Główny dworzec kolejowy & 112 \\
\hline 21 & Pomnik Starego Marycha & 110 \\
\hline 22 & Muzeum Archeologiczne w Poznaniu & 93 \\
\hline 23 & INEA Stadion & 91 \\
\hline 24 & Kościół Franciszkanów & 89 \\
\hline 25 & Pomnik Poznańskiego Czerwca 1956 & 59 \\
\hline 26 & Blubry 6D - poznańskie legendy & 54 \\
\hline 27 & Uniwersytet im. Adama Mickiewicza & 52 \\
\hline 28 & Muzeum Instrumentów Muzycznych & \\
\hline 29 & Pomnik Pogromców Enigmy & 58 \\
\hline 30 & Park Sołacki & \\
\hline & & \\
\hline
\end{tabular}

Źródło: opracowanie własne.
Tab. 2. Frekwencja w obiektach turystycznych w Poznaniu

\begin{tabular}{|r|l|r|}
\hline \multicolumn{1}{|c|}{ Lp. } & \multicolumn{1}{|c|}{ Nazwa atrakcji } & 2015 r. \\
\hline 1 & Termy Maltańskie & 936900 \\
\hline 2 & Stare Zoo w Poznaniu & 315135 \\
\hline 3 & Palmiarnia Poznańska & 157690 \\
\hline 4 & Brama Poznania & 96276 \\
\hline 5 & Wielkopolskie Muzeum Niepodległości & 86843 \\
\hline 6 & Muzeum Narodowe w Poznaniu & 78500 \\
\hline 7 & Pływalnia Chwiałka & 72580 \\
\hline 8 & Muzeum Archeologiczne w Poznaniu & 52283 \\
\hline 9 & Makiety Dawnego Poznania & 50845 \\
\hline 10 & INEA Stadion & 25657 \\
\hline 11 & Rezerwat Archeologiczny Genius loci & 23533 \\
\hline 12 & Lech Browary Wielkopolski & 21046 \\
\hline 13 & Muzeum Wiedzy o Srodowisku & 16243 \\
\hline 14 & Muzeum Instrumentów Muzycznych & 11585 \\
\hline 15 & Muzeum Archidiecezjalne & 11413 \\
\hline 16 & Ogród Dendrologiczny UP w Poznaniu & 10000 \\
\hline 17 & Fort III & 6850 \\
\hline 18 & Muzeum Bambrów Poznańskich & 4768 \\
\hline 19 & Salon Muzyczny Feliksa Nowowiejskiego & 2006 \\
\hline 20 & $\begin{array}{l}\text { Pracownia-Muzeum Józefa Ignacego Kraszew- } \\
\text { skiego }\end{array}$ & 1631 \\
\hline 21 & Prezydencki schron przeciwatomowy & 1511 \\
\hline 22 & Mieszkanie-Pracownia K. Iłłakowiczówny & 756 \\
\hline & & \\
\hline
\end{tabular}

Źródło: opracowanie własne na podstawie badania przeprowadzonego przez KRUCZKA (2016b, s. 122-125) oraz raportu Poznańskiej Lokalnej Organizacji Turystycznej (2016, s. 15).

W wyniku przeprowadzonej analizy uzyskano informacje na temat rozmieszczenia najchętniej ocenianych obiektów w Poznaniu (według użytkowników serwisu TripAdvisor). Na pierwszej z map wynikowych (rys. 1), przedstawiono lokalizację atrakcji turystycznych oraz dworca kolejowego i lotniska. Najpopularniejsze obiekty w Poznaniu (zarówno zabytki i muzea, jak i parki, ogrody oraz obiekty sportowe) rozmieszczone są głównie w jego centralnej części, na obszarze Starego Miasta.

Najczęściej oceniane hotele, restauracje i atrakcje turystyczne w Poznaniu znajdują się w wyraźnym skupisku w centrum miasta (rys. 2). Niewielu turystów decyduje się na hotel znacznie oddalony od centrum, najczęściej również wybierają oni restauracje zlokalizowane w centralnej części Poznania.

Na mapie skupień (rys. 3) widać, że najwięcej chętnie odwiedzanych atrakcji turystycznych jest zlokalizowanych wokół Starego Rynku i jego okolic. Na mapie wynikowej ciemnym kolorem oznaczony został obszar o największym zagęszczeniu obiektów. Niewiele spośród atrakcji turystycznych, wytypowanych $\mathrm{w}$ rankingu, znajduje się poza tą strefą. Zainteresowanie Starym Miastem wynika prawdopodobnie z dużej różnorodności, jaką oferuje jego obszar, rozlokowane są tam bowiem zabytki architektoniczne, np. kamieniczki, renesansowy ratusz i kościół farny, a także nowo utworzone obiekty, jak muzea czy parki. 


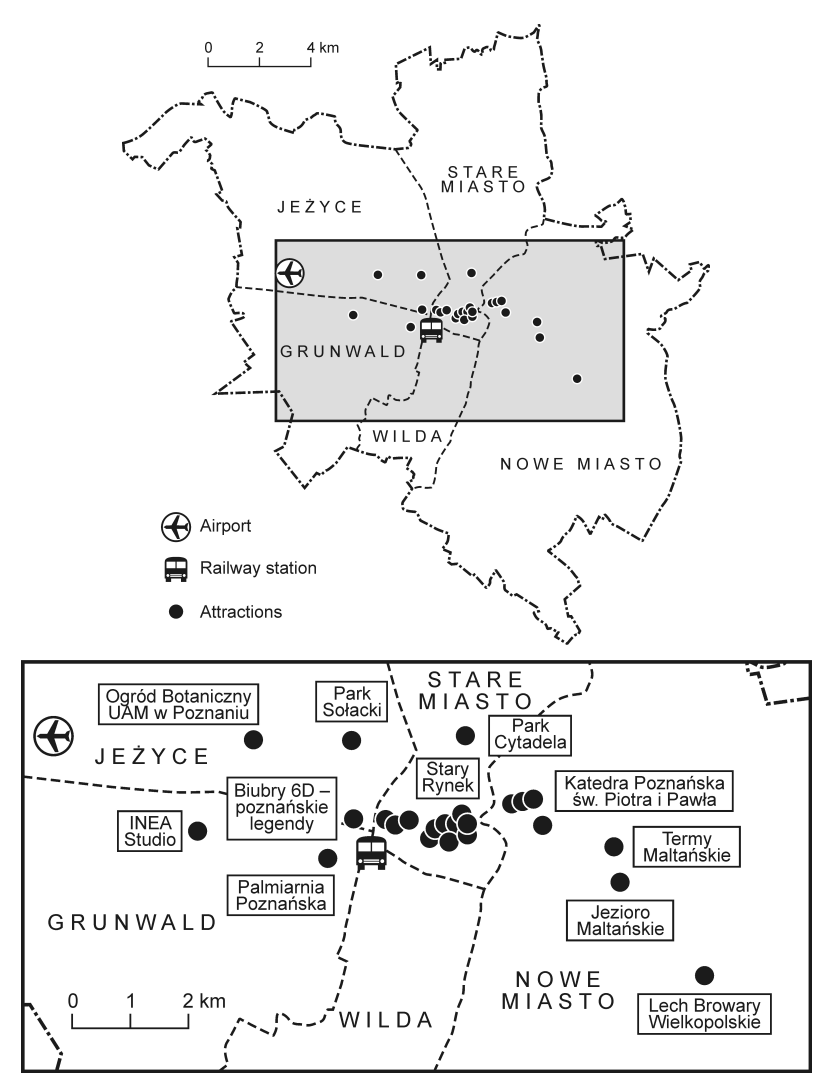

Rys. 1. Rozmieszczenie najczęściej ocenianych atrakcji turystycznych w Poznaniu Źródło rys. 1-5: opracowanie własne

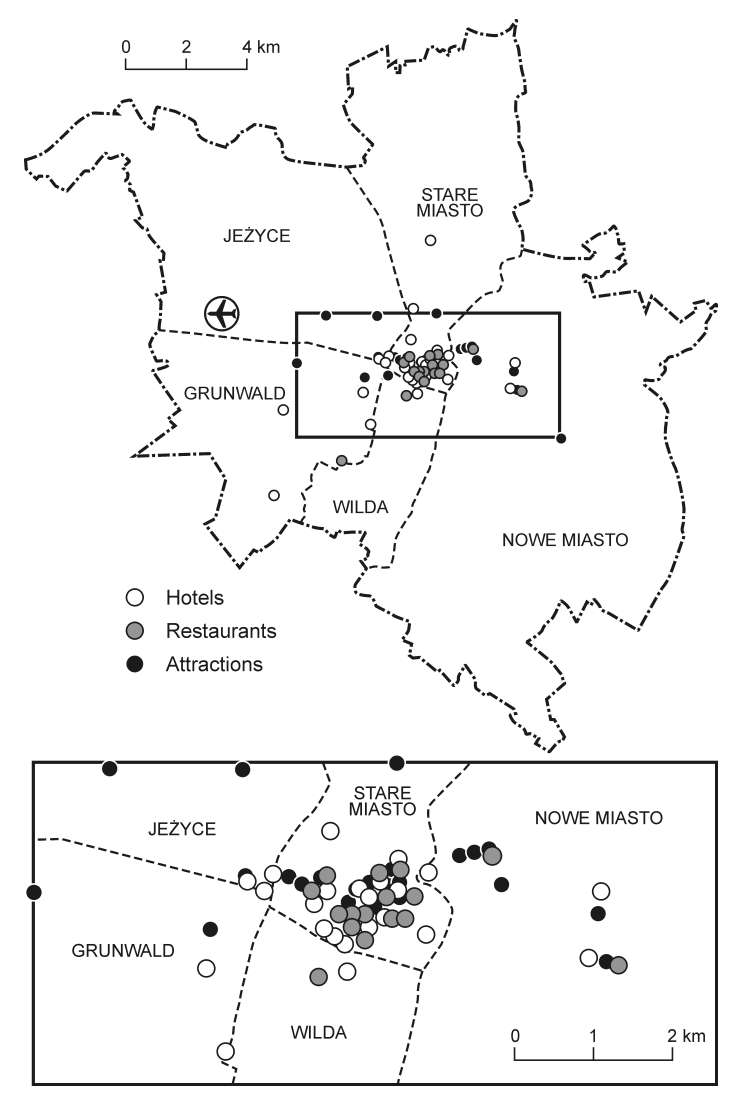

Rys. 2. Najczęściej oceniane hotele, restauracje i atrakcje turystyczne w Poznaniu

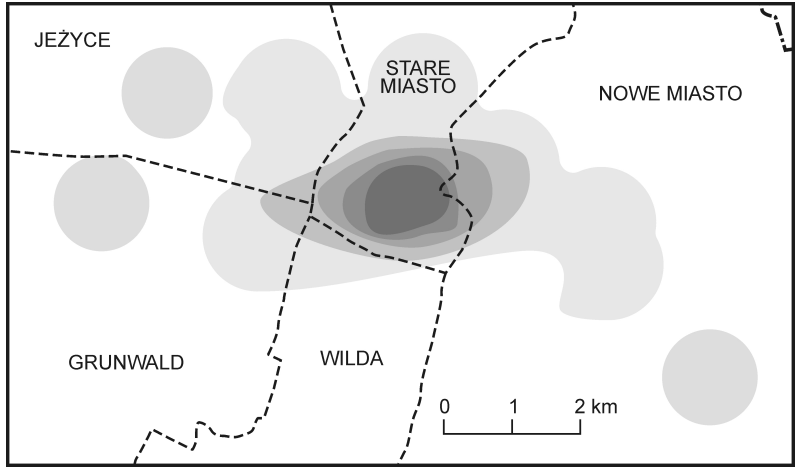

Rys. 3. Mapa skupień dla najczęściej ocenianych atrakcji turystycznych

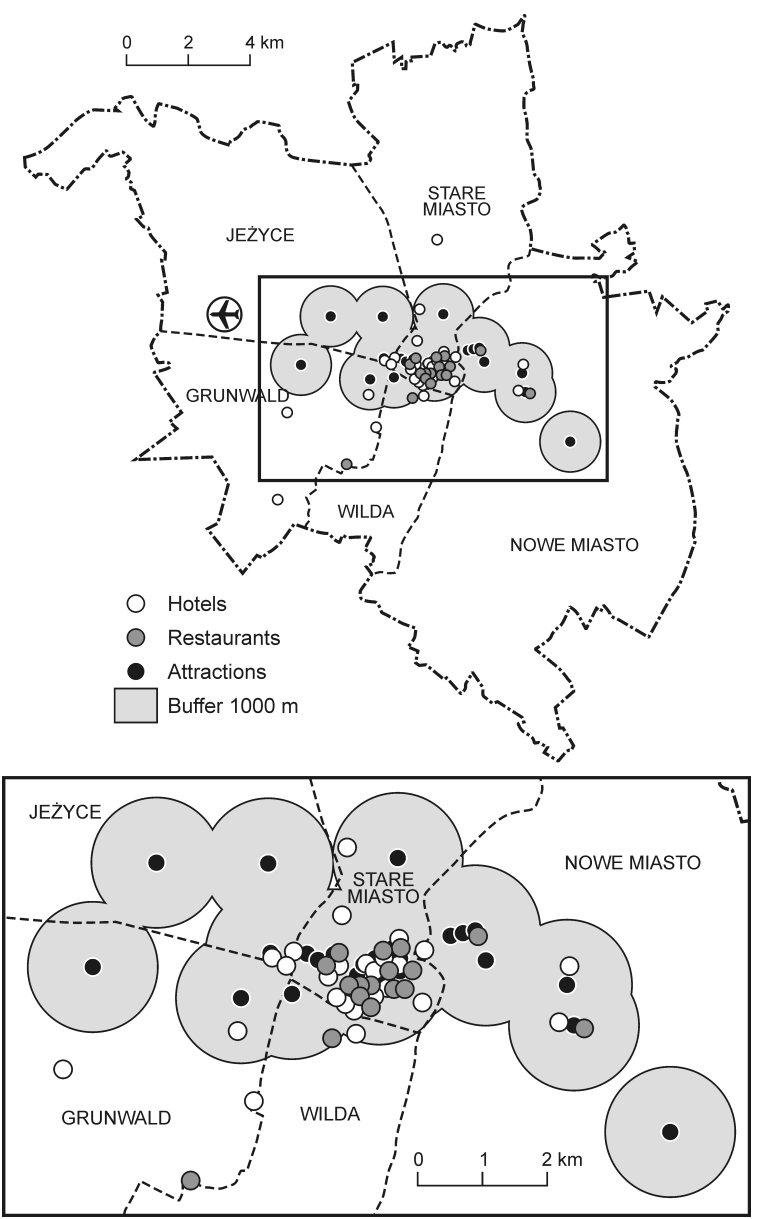

Rys. 4. Bufory $1000 \mathrm{~m}$ dla atrakcji turystycznych w Poznaniu

Strefy buforowe, utworzone wokół najchętniej odwiedzanych atrakcji turystycznych (rys. 4), pokazują, że zarówno hotele, jak i restauracje, wybierane przez użytkowników, zlokalizowane są w niewielkiej odległości od atrakcji, czyli w obszarze ich stref buforowych, wyznaczonych za pomoca ekwidystanty $1000 \mathrm{~m}$. W strefie buforowej znajduje się 29 restauracji cieszących się największym zainteresowaniem. Tylko cztery hotele spośród 30 będących w rankingu znajdują się 
poza wszystkimi strefami buforowymi, tzn. są rozlokowane w odległości większej niż 1000 m od jakiejkolwiek atrakcji.

Stosując metodę diagramu Woronoja (rys. 5), wykreślono poligony, stanowiące obszary, na których odległości między poszczególnymi atrakcjami są mniejsze niż pomiędzy innymi. Pozwala to sądzić, że istnieje duże prawdopodobieństwo, że turysta znajdujący się na terenie mniejszego poligonu, odwiedzi atrakcje zlokalizowane na poligonach sąsiednich. Przypuszczalnie skorzysta również z usług restauracji i któregoś z hoteli znajdujących się w pobliżu.

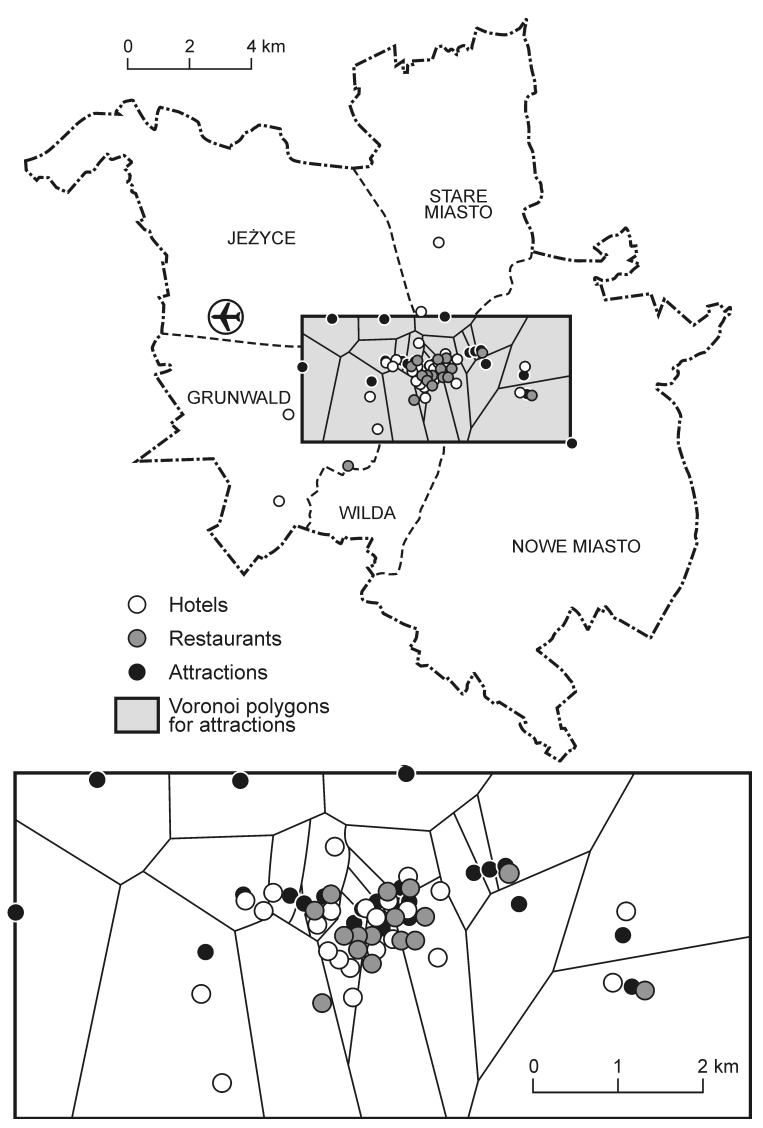

Rys. 5. Poligony Woronoja dla atrakcji turystycznych

Wykreślone poligony są wyraźnie mniejsze dla centralnej części miasta, co pokazuje duże zainteresowanie tym obszarem. Cały obszar zidentyfikowany za pomocą tej metody stanowi niewielką część miasta i potencjalnie może świadczyć o granicach terenu, na którym odbywa się największy ruch turystyczny.

\section{WNIOSKI}

Przeprowadzona analiza pozwoliła na zlokalizowanie obiektów najczęściej wybieranych przez użytkowników portalu TripAdvisor. Określono również obszary największego zagęszczenia najpopularniejszych atrakcji, a także obszar, na którym odbywa się największy ruch turystyczny, przy założeniu, że liczba ocen wprost proporcjonalnie przekłada się na liczbę odwiedzin.

Postawiona hipoteza, dotycząca możliwości wykorzystania źródła danych, jakim są media społecznościowe, na potrzeby planowania turystyki w skali lokalnej, okazała się prawdziwa.

Porównanie wyników z prowadzonymi dotychczas badaniami z wykorzystaniem wiarygodnych metod częściowo potwierdziło skuteczność tej metody. Specyfika danych pochodzących z serwisów społecznościowych powoduje, że są one obszerniejsze niż dane gromadzone innymi metodami i na równi traktują obiekty ewidencjonujące liczbę odwiedzających i te, w przypadku których takich statystyk się nie prowadzi (np. parki miejskie, kościoły czy pomniki).

Pozyskanie danych przez zespoły planistyczne pozostaje obecnie dużym wyzwaniem. Przedstawiona koncepcja może stanowić uzupełnienie luk informacyjnych, dotyczących ruchu turystycznego, w kontekście danego regionu. Zastosowana metoda charakteryzuje się wysokim stopniem uniwersalności - może służyć do analizy dowolnej destynacji turystycznej, posiadającej odpowiednio wysoką liczbę ocen. Bazy danych tego typu, przy cyklicznej aktualizacji, pozwalają na szybkie zidentyfikowanie pojawiających się trendów, w przeciwieństwie do innych metod (np. zbierania danych za pomocą kwestionariusza ankiety), które w momencie wykorzystania mają już charakter historyczny. Ta forma gromadzenia i analizy danych stanowić może służyć rozwiązywaniu problemów planistycznych pojawiających się w dynamicznym środowisku, z którym mamy obecnie do czynienia.

Wiele kwestii nadal wymaga szczegółowego opracowania, przede wszystkim w aspekcie metodycznym. Do podstawowych należy uproszczenie procesu gromadzenia danych i generowania banku informacji o przejrzystej strukturze i wysokiej jakości. Wymaga to utworzenia wielu narzędzi usprawniających ten proces (takich jak np. programy automatycznie gromadzące dane), tak aby nie był on kapitało- i czasochłonny. Również metody analizy tego typu banków danych są czymś nowym i wymagają rozpoznania. Określenie cech badanej grupy turystów stanowi także istotną kwestię. Nie należy domniemywać, że jest to proste odzwierciedlenie struktury społeczeństwa. Należałoby postawić w tym miejscu wiele pytań, pozwalających na doprecyzowanie informacji o użytkownikach mediów społecznościowych. Kim są? Co ich motywuje do umieszczania opinii? Do jakich grup wiekowych należą? A także wiele innych, pozwalających na określenie, jaki segment klientów reprezentują.

Pozyskiwanie danych $\mathrm{z}$ serwisów społecznościowych jest zadaniem trudnym i wymaga ciągłego uczenia się, modyfikowania już wypracowanych metod 
i opracowywania zupełnie nowych, pozwalających na uzyskiwanie informacji z kolejnych źródeł. Dynamiczny rozwój i wzrost znaczenia MS spowodował, że nie sposób już przechodzić obok nich obojętnie. Potencjał, drzemiący w nowych rozwiązaniach, został już dostrzeżony, jednak badacze dopiero oswajają się ze zmianami, które nastąpiły, przecierają nowe szlaki i tworzą narzędzia na miarę nowych czasów.

\section{BIBLIOGRAFIA}

AYEH J.K., AU N., LAW R., 2013, „Do we believe in TripAdvisor?” Examining credibility perceptions and online travelers' attitude toward using user-generated content, "Journal of Travel Research", 52 (4), s. 437-452.

BANERJEE S., CHUA A.Y.K., 2013, Reliability of reviews on the Internet: The case of TripAdvisor, World Congress on Engineering and Computer Science, San Francisco.

BERTHON P.R. i in., 2012, Marketing meets Web 2.0, social media, and creative consumers: Implications for international marketing strategy, „Business Horizons", 55 (3), s. 261-271.

BRZEZIŃSKI S., JASIŃSKI M., 2014, Media społecznościowe w marketingu terytorialnym polskich miast, "Marketing i Rynek”, 3, s. 9-17.

CHAN N.L., GUILLET B.D., 2011, Investigation of social media marketing: How does the hotel industry in Hong Kong perform in marketing on social media websites?, ,Journal of Travel \& Tourism Marketing", 28 (4), s. 345-368.

FOTIS J., BUHALIS D., ROSSIDES N., 2012, Social media use and impact during the holiday travel planning process, Paper presented at the $1^{\text {th }}$ international conference on information and communication technologies in travel and tourism (ENTER), January 25-27, 2012. Sweden: Helsingborg.

HAYS S., PAGE S. J., BUHALIS D., 2013, Social media as a destination marketing tool: Its use by national tourism organisations, "Current Issues in Tourism", 16 (3), s. 211-239.

HOWE J., 2009, Crowdsourcing: Why the power of the crowd is driving the future of business, Three Rivers Press, Nowy Jork.

KAPLAN A.M., HAENLEIN M., 2010, Users of the world, unite! The challenges and opportunities of social media, „Business Horizons", 53 (1), s. 59-68.

KRUCZEK Z., 2016a, Frekwencja w polskich atrakcjach turystycznych. Problemy oceny liczby odwiedzajacych, "Ekonomiczne Problemy Turystyki", 35, s. 25-35, https://doi.org/10.18276/ept. 2016.3.35-02
KRUCZEK Z., 2016b, Frekwencja w atrakcjach turystycznych w latach 2011-2015, Polska Organizacja Turystyczna, KrakówWarszawa.

KWOK L., YU B., 2013, Spreading social media messages on Facebook, "Cornell Hospitality Quarterly", 54 (1), s. 84-94.

LIU Z., SIGUAW J.A., ENZ C.A., 2008, Using tourist travel habits and preferences to assess strategic destination positioning: The case of Costa Rica, „Cornell Hospitality Quarterly”, 49 (3), s. 258-281.

MCAFEE A., BRYNJOLFSSON E., 2012, Big data: The management revolution, „Harvard Business Review”, 90 (10), s. 61-67.

MiguÉNS J., BAGGIO R., COSTA C., 2008, Social media and tourism destinations: TripAdvisor case study, "Advances in Tourism Research", 26 (28), s. 26-28.

MUNAR A.M., JACOBSEN J.K. S., 2014, Motivations for sharing tourism experiences through social media, "Tourism Management", 43 , s. $46-54$.

O'REILLY T., 2005, What is Web 2.0, O'Reilly Media, https:/ / www. oreilly. $\backslash \mathrm{com} / \mathrm{pub} / \mathrm{a} /$ web2/archive/what-is-web-20.html.

PHILliPS P., MOUTINHO L., 2014, Critical review of strategic planning research in hospitality and tourism, "Annals of Tourism Research", 48, s. 96-120.

POLAŃSKA K., WASSILEW A., 2015, Analizy big data w serwisach społecznościowych, „Nierówności Społeczne a Wzrost Gospodarczy", 44 (4/2015), s. 117-128.

PUdeŁKO M., 2017, Prawdziwa historia Internetu, wyd. 3, Itstart, Warszawa.

SZROMNIK A., 2012, Marketing terytorialny, http://images.iformat. pl/195911E5EB/84EC0342-6DCD-4477-84F9-1BB7324257A8. pdf.

Tripadvisor, Dochodzenie: kara więzienia za zamieszczanie fałszywych recenzji, 2018, https://pl.tripadvisor.com/TripAdvisor Insights/w4237.

UNWTO, 2017, Tourism Highlights 2017 Edition, https://www.eunwto.org/doi/pdf/10.18111/9789284419029.

XIANG Z., GRETZEL U., 2010, Role of social media in online travel information search, ",Tourism Management", 31 (2), s. 179-188.

ZAJADACZ A., 2017, Media społecznościowe w procesie planowania rozwoju turystyki w skali regionalnej, ,Ekonomiczne Problemy Turystyki", 1 (37) 2017, s. 127-146.

https://www.alexa.com/siteinfo/tripadvisor.com.

https://www.alexa.com/siteinfo/yelp.com.

https://www.tripadvisor.com.

https:/ / www.tripadvisor.mediaroom.com.

Artykuł wpłyną: 2 października $2018 \mathrm{r}$ Zaakceptowano do druku: 28 listopada $2018 \mathrm{r}$. 